\title{
Determining Optimum Generator for South-East Coast of Bangladesh: Hybrid, Solar-Only or Wind- Only?
}

\author{
Anjan Debnath ${ }^{1, *}$, M. Nazmul Huda ${ }^{2}$, Chitta Saha ${ }^{2}$ and Sukanta Roy ${ }^{3}$ \\ ${ }^{1}$ Department of Science and Maths, Asian University for Women, Bangladesh \\ ${ }^{2}$ School of Computing, Electronics and Maths, Coventry University, UK \\ ${ }^{3}$ Bangla Trac Ltd, Bangladesh. \\ *anjanbuet02@gmail.com, anjan.debnath@auw.edu.bd.
}

\begin{abstract}
In this study, the optimal conditions for renewable sources, Solar and Wind generators, have been determined for irrigation system in Sandwip, St. Martin and Kutubdia of Bangladesh by conducting a linear programming graphical analysis tool. For all of these three regions mentioned above, the optimum system is found to be solar-only system for irrigation based on the load conditions and meteorological data. Finally, the study shows the amount of energy the optimum PV generator has produced in a year with the surplus energy after satisfying the load demand.
\end{abstract}

Index Terms - Solar Energy, Wind Energy, Irrigation, Optimum system, Load, Hybrid

\section{INTRODUCTION}

The geographic location of Bangladesh has made herself a great potential of employing solar irradiation. Bangladesh receives an average of $4-6.5 \mathrm{kWh} / \mathrm{m}^{2}$ of solar radiation daily. This can produce a total of $1018 \times 10^{18} \mathrm{~J}$ of energy, of which about $0.11 \%$ can meet the primary energy consumption of this country [1]. For water pumping, there are plenty of renewable sources, amongst photovoltaic solar pumping turns out to be the most suitable one. Because it is clean and naturally available, it seems to have very good correlation between its availability and water demand [2]. This trend is also same in Bangladesh also. This photovoltaic system then can be incorporated with fast MPPT in order to extract the maximum efficiency given the rapid weather change in Bangladesh [3]. This is of utmost importance since the country has a huge amount of almost 1.61 million irrigation pumps out of which 1.34 million (about $83 \%$ ) is running by diesel and 0.27 million (about $16 \%$ ) is running by electricity. These pumps are consuming $700 \mathrm{MW}$ of electricity and 900 million liters of diesel every year [1].

Another research found that the wind speed is very high in south east coastal regions of Bangladesh, located along the Bay of Bengal such as Kuakata, Sandwip and St. Martin Islands [4]. Water pumping irrigation system would be a suitable solution for them since they cannot get connected to national grid. In that regard, the objective of this study is to carry out a feasibility study using a mathematical tool in order to find the most viable solution of PV and Wind generators considering the load and weather conditions.

\section{METHODOLOGY}

The Graphical linear programming sizing tool has been utilized which is then used for the daily averages of the solar and wind energy values for Sandwip, St. Martin's Island and Kutubdia regions of Bangladesh.

The sizes of the two generators Solar and Wind Generator have been defined as As and Aw in terms of the conversion efficiency multiplied by the effective area (A) of the generator. Thus, for the PV array, we have:

$$
\text { As }=\mathrm{n} * \mathrm{~A}
$$

Where, $\mathrm{n}$ : efficiency, As: solar panel area in $\mathrm{m}^{2}$ For the Wind Generator:

$$
\mathrm{Aw}=\mathrm{Cp} * \pi * \mathrm{r}^{2}
$$

Where, Aw: wind turbine area in $\mathrm{m}^{2}, \mathrm{Cp}$ : power coefficient, r: radius of the turbine.

The energy resources will be described by the average daily energy incident on a unit area. For the solar energy S, the required value refers to the inclined plane of the modules which is usually calculated from the meteorological data for a horizontal plane. The wind energy $\mathrm{W}$ is measured in a plane perpendicular to the wind direction, the following equation is normally used:

$$
\mathrm{W}=\left(\frac{1}{2}\right) * \mathrm{D} * \rho_{\mathrm{AIR}} * \mathrm{v}^{3}
$$

Where, $\rho_{\text {AIR }}$ : air density in $\mathrm{kg} / \mathrm{m}^{3}$, v: average wind velocity in $\mathrm{m} / \mathrm{s}$, D: Duration of 1 day, i.e. 24 hours

The assumption is that the monthly average daily Load (here it is water demand) over the year is known, we can then write down the following condition which satisfies the demand load:

$$
\mathrm{S} * \mathrm{As}+\mathrm{W} * \mathrm{Aw} \geq \mathrm{L}
$$

\section{S: Solar Energy in $\mathrm{KWh} / \mathrm{m}^{2}$ \\ $\mathrm{W}$ : Wind Energy in $\mathrm{KWh} / \mathrm{m}^{2}$ \\ $\mathrm{L}$ : Load demand in $\mathrm{KWh}$}

The main objective is to characterize the optimized values of As and Aw that satisfies the above equation at all times of the year using the average values of $\mathrm{S}, \mathrm{W}$ and $\mathrm{L}$ and then plugging those As and Aw values in (5) to minimize the cost function.

$$
C w * A w+C s * A s
$$

Cw: cost of wind turbine $/ \mathrm{m}^{2}$ 
Cs: cost of solar panel / $\mathrm{m}^{2}$

Here $\mathrm{Cs}$ and $\mathrm{Cw}$ have been chosen as 100 unit currency and 150 unit currencies respectively. The following data and curve have been generated from NASA website [5].

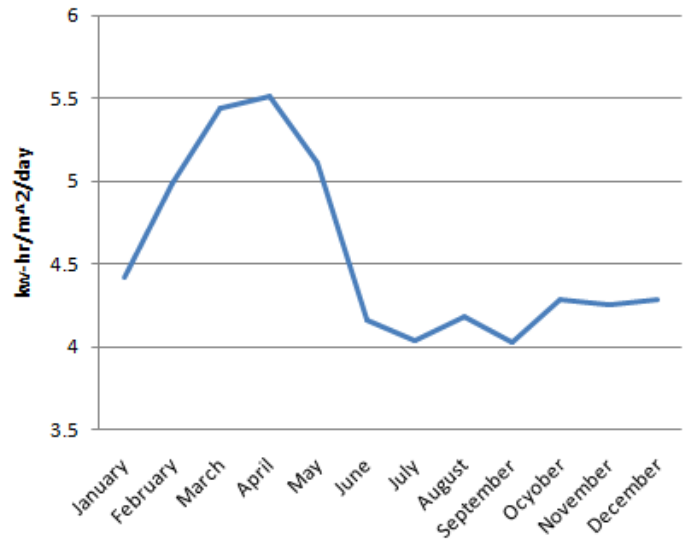

Fig. 1 Graph of Monthly average daily Solar Energy in Sandwip [5]

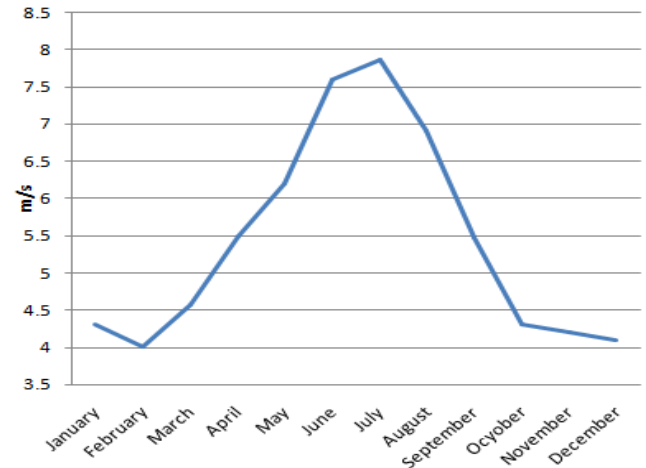

Fig. 2 Graph of Monthly average daily Wind Speed in Sandwip [5]

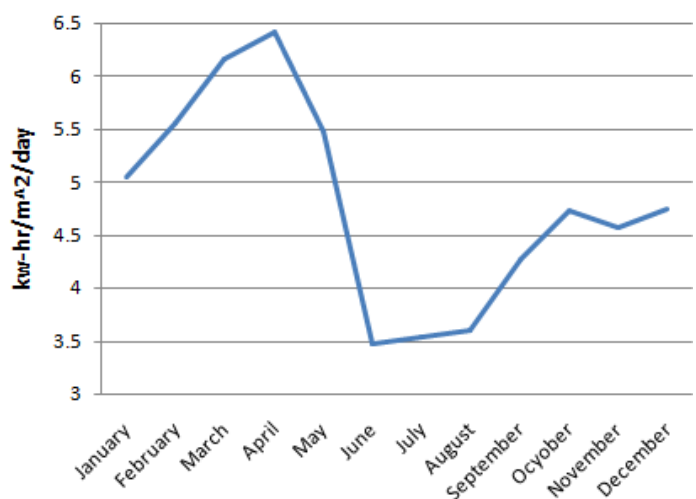

Fig. 3 Graph of Monthly average daily Solar Energy in St. Martin's Island [5]

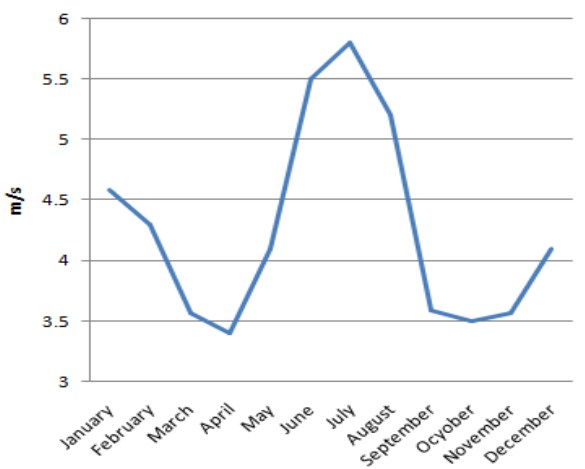

Fig. 4 Graph of Monthly average daily Wind Speed in St. Martin's Island [5]

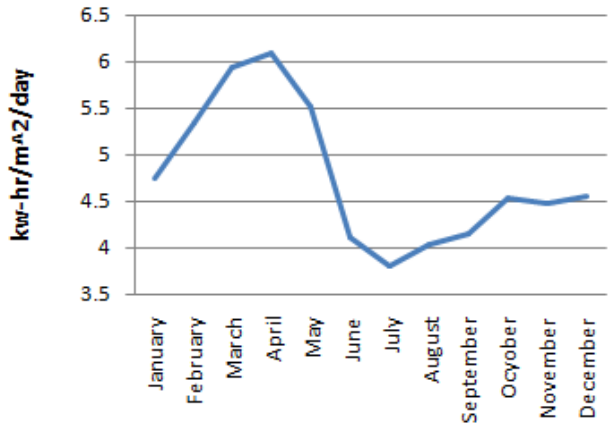

Fig. 5 Graph of Monthly average daily Solar Energy in Kutubdia [5]

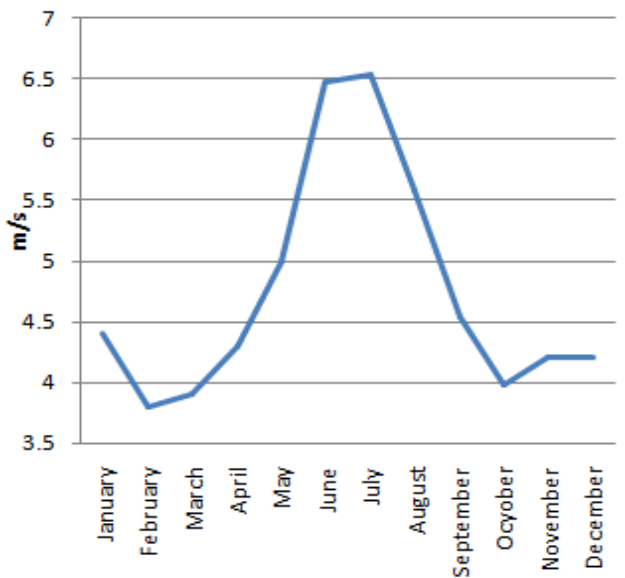

Fig. 6 Graph of Monthly average daily Wind Speed in Kutubdia [5]

The wind velocity of Fig. 2, Fig. 4 and Fig. 6 have been converted into Wind energy, W using equation (3) and the following table has been generated:

TABLE I

MONTHLY AVERAGE DAILY SOLAR ENERGY AND WIND ENERGY IN SANDWIP, ST. MARTIN ISLAND AND KUTUBDIA

\begin{tabular}{|c|c|c|c|c|c|c|}
\hline & \multicolumn{2}{|c|}{ Sandwip } & \multicolumn{2}{|c|}{ St. Martin } & \multicolumn{2}{|c|}{ Kutubdia } \\
\hline & $\begin{array}{l}\text { Solar } \\
\text { Energ } \\
\mathbf{y}, \mathbf{S} \\
(\mathbf{K W} \\
\left.\mathbf{h} / \mathbf{m}^{2}\right)\end{array}$ & $\begin{array}{l}\text { Wind } \\
\text { Energy } \\
, \text { W } \\
(\text { KWh/ } \\
\left.\mathbf{m}^{2}\right)\end{array}$ & $\begin{array}{l}\text { Solar } \\
\text { Energy } \\
, \mathbf{S} \\
(\mathrm{KWh} / \\
\left.\mathbf{m}^{2}\right)\end{array}$ & $\begin{array}{l}\text { Wind } \\
\text { Energy } \\
, \text { W } \\
(\mathrm{KWh} / \\
\left.\mathbf{m}^{2}\right)\end{array}$ & $\begin{array}{l}\text { Solar } \\
\text { Energy } \\
, \mathbf{S} \\
(\mathrm{KWh} / \\
\left.\mathrm{m}^{2}\right)\end{array}$ & $\begin{array}{l}\text { Wind } \\
\text { Energy } \\
, \text { W } \\
(\mathbf{K W h} / \\
\left.\mathbf{m}^{2}\right)\end{array}$ \\
\hline Jan & 4.42 & 0.38 & 5.04 & 0.46 & 4.75 & 0.40 \\
\hline Feb & 4.98 & 0.32 & 5.56 & 0.36 & 5.33 & 0.29 \\
\hline Mar & 5.44 & 0.50 & 6.16 & 0.25 & 5.93 & 0.30 \\
\hline Apr & 5.51 & 0.79 & 6.41 & 0.19 & 6.09 & 0.37 \\
\hline May & 5.11 & 1.08 & 5.48 & 0.32 & 5.52 & 0.59 \\
\hline Jun & 4.16 & 2.07 & 3.47 & 0.80 & 4.11 & 1.25 \\
\hline Jul & 4.04 & 2.30 & 3.54 & 0.94 & 3.81 & 1.39 \\
\hline Aug & 4.18 & 1.60 & 3.60 & 0.64 & 4.03 & 1.01 \\
\hline Sep & 4.02 & 0.76 & 4.27 & 0.30 & 4.15 & 0.48 \\
\hline Oct & 4.28 & 0.38 & 4.73 & 0.20 & 4.53 & 0.29 \\
\hline Nov & 4.25 & 0.35 & 4.57 & 0.27 & 4.48 & 0.34 \\
\hline Dec & 4.28 & 0.33 & 4.74 & 0.31 & 4.56 & 0.34 \\
\hline
\end{tabular}

\section{MODELLING OF LOAD}

Table II shows the average water requirement for main crops of Bangladesh [6]. The monthly average precipitation is shown in Fig. 7. A typical $1.1 \mathrm{~kW}$ solar pump has a flow rate 
of 55 LPM with $20 \mathrm{~m}$ water head [6]. So, at rated power the solar pump can lift 3300 lit/hour. One hectare of sample land has been taken into consideration for irrigation. Then, the monthly averaged daily water pumping load can be calculated as follows [6]:

$$
L d=\frac{W c-W p}{30(F p * 60)}
$$

where, Ld is the deferrable monthly averaged daily water pumping load ( $\mathrm{kWh} /$ day), $\mathrm{Wc}$ is the monthly water need for crops (lit/month), $\mathrm{Wp}$ is the monthly averaged precipitation (lit/month), and Fp is the flow rate of the pump (lit/min). Fig. 8 shows the monthly averaged daily load profile of load that has been used in this study [6]. Since the irrigation requirement is high in the winter, the required irrigation load is also highest in the months from November to February. The heavy rainfall in the rainy season which is May to September makes the irrigation load requirement almost close to zero. However, the intermittent nature of the renewable energy sources demands to include an extra $0.5 \mathrm{kWh} /$ day load which has been depicted in Fig. 8 .

TABLE II

THE NEED OF WATER FOR IRRIGATION OF CROPS [6]

\begin{tabular}{|l|l|l|}
\hline Crop & Irrigation Period & $\begin{array}{l}\text { Water } \\
\text { Volume }\left(\mathbf{m}^{\mathbf{3} / h e c t a r e}\right)\end{array}$ \\
\hline Rice - Aush & July - August & 650 \\
\hline Rice - Aman & Sept - Oct & 700 \\
\hline Rice - Boro & Feb - March & 750 \\
\hline Mustard & Dec - Jan & 300 \\
\hline Wheat & Feb - March & 700 \\
\hline Maize & Oct - Jan & 152 \\
\hline Potato & Jan - Feb & 283 \\
\hline Lentil & Jan - Feb & 700 \\
\hline
\end{tabular}

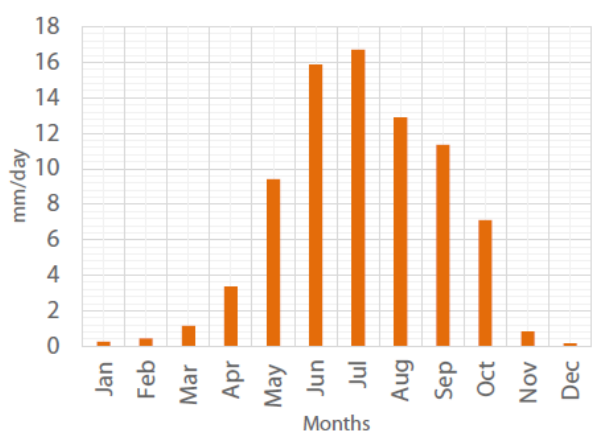

Fig. 7 Monthly Averaged Yearly Precipitation: 13 years average [6]

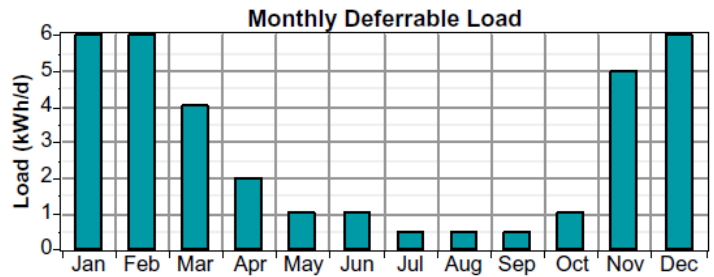

Fig. 8 Monthly average daily deferrable water pumping load [6]

\section{RESULTS AND DISCUSSIONS}

Using the constraint equation (4) and Table I Solar and Wind energy data, the following figures Fig. 9, Fig. 10, Fig. 11 have been generated for the three study regions of Bangladesh.

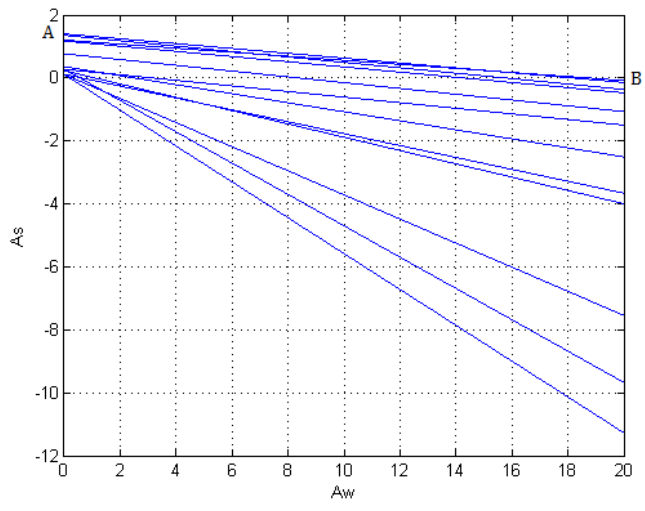

Fig. 9 Plot of equation (4) for all 12 months data of Table I of Sandwip

Each and every line in Fig. 9, Fig. 10 and Fig. 11 representing equation (4) which means, the load demand has been satisfied by Solar and Wind generators along those 12 lines for all 12 months. However, line $\mathrm{AB}$ in Fig. 9 is the desired optimum boundary line where Solar and Wind generators satisfy the load demand for any month, similar is true for line CD in Fig. 10 and EF and FG lines in Fig. 11. The approximated equations of lines $\mathrm{AB}, \mathrm{CD}, \mathrm{EF}$ and $\mathrm{FG}$ are given below:

$$
\begin{aligned}
& A s=-0.0771 * A w+1.4020 \\
& A s=-0.0654 * A w+1.266 \\
& A s=-0.0746 * A w+1.316 \\
& A s=-0.0543 * A w+1.1233
\end{aligned}
$$

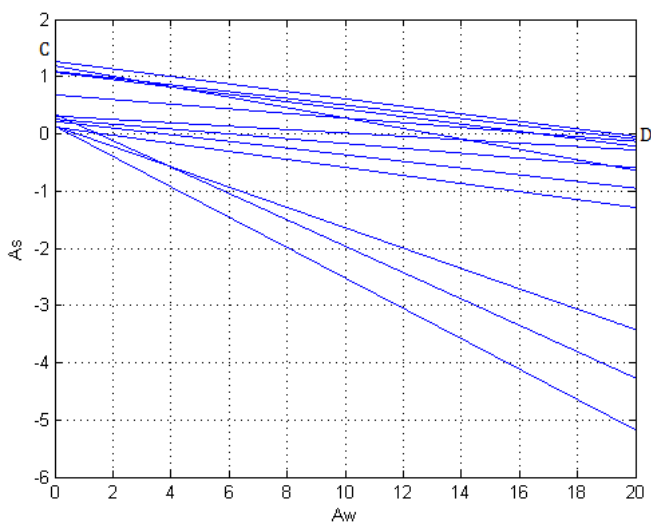

Fig. 10 Plot of equation (4) for all 12 months data of Table I of St. Martin Island

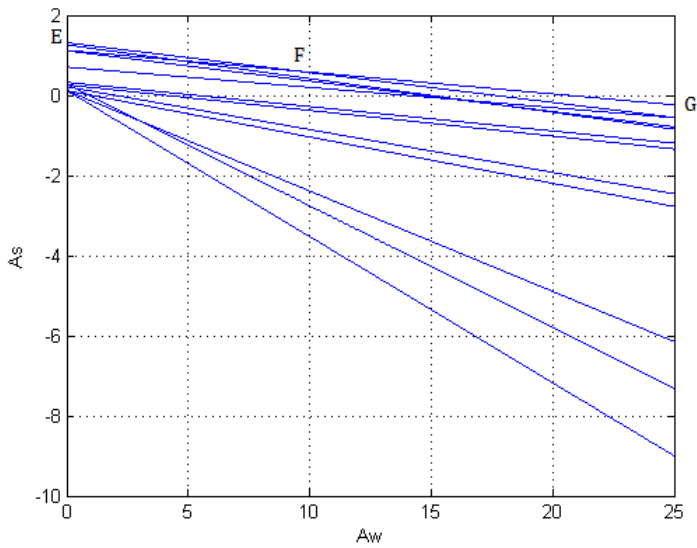

Fig. 11 Plot of equation (4) for all 12 months data of Table I of Kutubdia 
Equations (7) to (10) are the boundary equations where the load demand for any month is satisfied by PV and Wind generators, therefore, these equations are taken into consideration for calculating the minimum cost of the system.

For line $\mathrm{AB}$ which is the optimum line for Sandwip, every point (Aw, As) on that line fulfil the load demand for any month. Starting from point A with very little interval, all the points on that line are plugged into equation (5) which produces an array of all cost values. Then from that array, the minimum cost value has been determined with corresponding Aw and As, similar process has been repeated for St. Martin's Island and Kutubdia also, represented by line $\mathrm{CD}$ with equation (8) and lines EF \& FG with equations (9) and (10) respectively. The following results have been produced using MATLAB programming which has been shown in Table III:

TABLE III

OPTIMUM VALUE OF SOLAR \& WIND GENERATOR AND COST IN SANDWIP, ST. MARTIN ISLAND AND KUTUBDIA

\begin{tabular}{|l|l|l|l|}
\hline & Sandwip & St. Martin & Kutubdia \\
\hline $\mathbf{A s}\left(\mathbf{m}^{\mathbf{2}}\right)$ & 1.402 & 1.266 & 1.316 \\
\hline $\mathbf{A w}\left(\mathbf{m}^{\mathbf{2}}\right)$ & 0 & 0 & 0 \\
\hline Cost & 140.2 & 126.6 & 131.6 \\
\hline
\end{tabular}

As Table III shows for the three regions, the solar-only system has been proven to be most optimum and cost effective solution. Fig. 12, Fig. 13, Fig. 14 illustrate the amount of energy the optimum PV generator produce for 12 months and satisfy the load demand. As we can see, the load matching has been very good for January, February, November and December, however, a bit high for other remaining months, specially, when the load is very low, consequently, producing excess energy. The total surplus energy has been calculated as 42.34 KWh, $38.58 \mathrm{KWh}$ and 41.09 KWh respectively for Sandwip, St. Martin and Kutubdia regions.

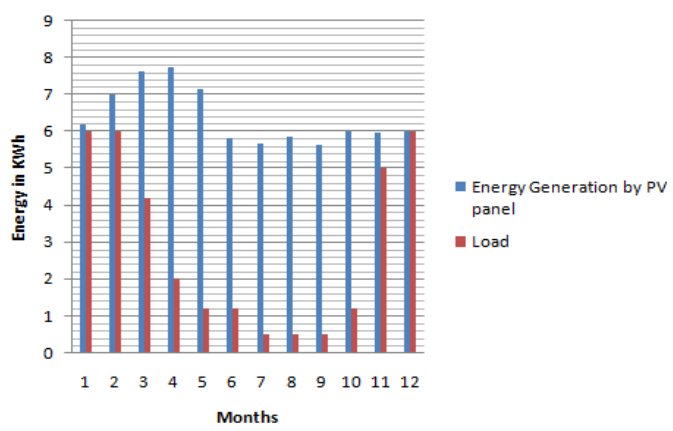

Fig. 12 Energy generation by optimized PV panel, As $=1.402 \mathrm{~m}^{2}$ for Sandwip

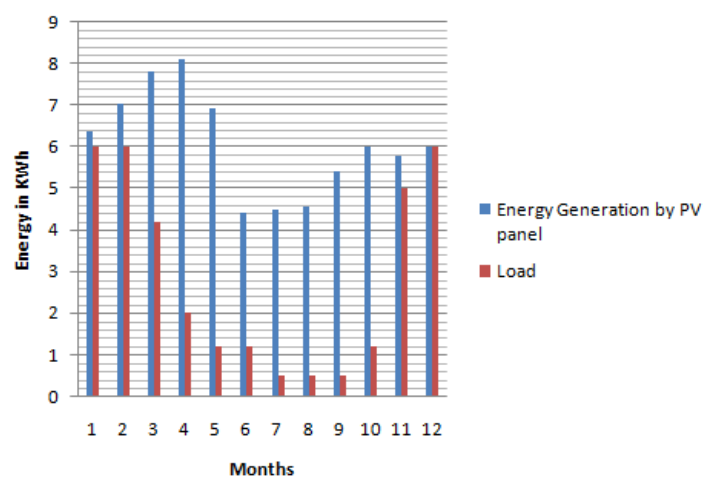

Fig. 13 Energy generation by optimized PV panel, As $=1.266 \mathrm{~m}^{2}$ for St. Martin

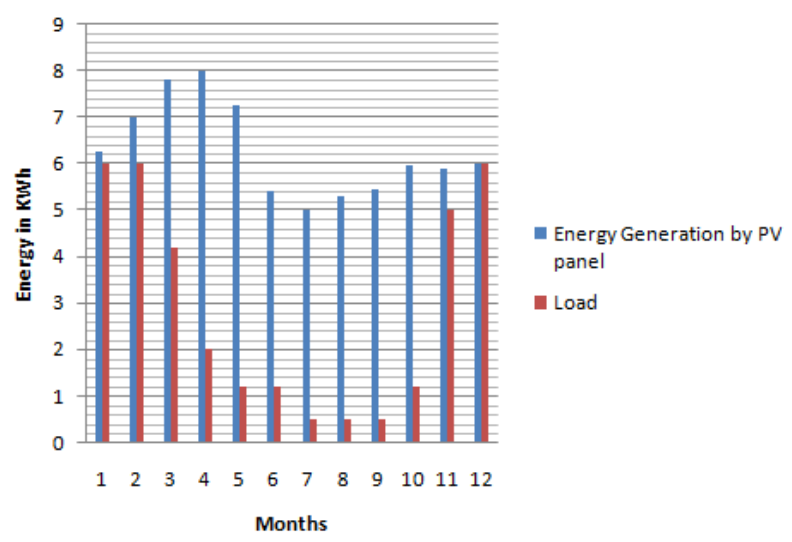

Fig. 14 Energy generation by optimized PV panel, As $=1.316 \mathrm{~m}^{2}$ for Kutubdia

\section{CONCLUSIONS}

The study employs a mathematical tool along with MATLAB programming to identify the optimal parameters of renewable energy generators, PV and/or Wind for water pumping irrigation system at 3 regions of Bangladesh. The research found the sole PV generator as a most desirable one given the water demand for irrigation system and weather data for those 3 regions. It also calculates the amount of extra energy the optimum PV generator produce over the year which could be utilized in the national grid or other purposes accordingly.

\section{REFERENCES}

[1] M. A. H. Baky, M. M. Rahman, and A. S. Islam, "Development of renewable energy sector in Bangladesh: Current status and future potentials," Renew. Sustain. Energy Rev., vol. 73, pp. 1184-1197, 2017.

[2] M. Aliyu, G. Hassan, S. A. Said, M. U. Siddiqui, A. T. Alawami, and I. M. Elamin, "A review of solar-powered water pumping systems," Renew. Sustain. Energy Rev., vol. 87, pp. 61-76, May 2018.

[3] A. Debnath, S. Roy, M. N. Huda, and M. Z. R. Khan, "Fast maximum power point tracker for photovoltaic arrays," in Electrical \& Computer Engineering (ICECE), 2012 7th International Conference on, 2012, pp. 912-915.

[4] M. A. Shaikh, K. A. Chowdhury, S. Sen, and M. M. Islam, "Potentiality of wind power generation along the Bangladesh coast," in AIP Conference Proceedings, 2017, vol. 1919, p. 020035.

[5] NASA, "POWER Data Access Viewer." [Online]. Available: https://power.larc.nasa.gov/data-access-viewer/. [Accessed: 14-Jul2018].

[6] M. N. I. Sarkar and H. R. Ghosh, "Techno-economic analysis and challenges of solar powered pumps dissemination in Bangladesh," Sustain. Energy Technol. Assess., vol. 20, pp. 33-46, 2017. 